\title{
Peranan BUMDesa dalam Meningkatkan Kemandirian Ekonomi Desa
}

\author{
Gayatri ${ }^{1}$ \\ Fakultas Ekonomi dan Bisnis \\ Universitas Udayana, Indonesia \\ Email: gayatri_akuntansi@unud.ac.id
}

\author{
Ni Luh Sari Widhiyani ${ }^{2}$ \\ Fakultas Ekonomi dan Bisnis \\ Universitas Udayana, Indonesia
}

\begin{abstract}
ABSTRAK
BUMDesa merupakan penjabaran dari visi pembangunan nasional yaitu terwujudnya Indonesia yang berdaulat, mandiri, dan berkepribadian berlandaskan gotong royong. Di Provinsi Bali baru $65 \%$ dari desa yang ada memiliki BUMDesa. BUMDesa diharapkan menjadi motor penggerak bagi ekonomi desa. Tujuan dari penelitian ini adalah untuk mengetahui peranan BUMDesa dalam meningkatkan kemandirian ekonomi desa. Populasi dalam penelitian ini adalah seluruh Badan Usaha Milik Desa yang terdapat di Provinsi Bali. Lokasi penelitian dilakukan di Kabupaten Gianyar. Teknik pengumpulan sampel menggunakan purposive sampling. Teknik pengumpulan data dilakukan melalui penyebaran kuesioner. Teknik analisis data menggunakan regresi linier berganda. Penelitian ini membuktikan bahwa secara parsial, kemandirian secara ekonomi berperanan positif terhadap BUMDesa di Kabupaten Gianyar. Kemandirian intelektual berperanan positif terhadap BUMDesa di Kabupaten Gianyar. Dan kemandirian berorganisasi berperanan positif terhadap BUMDesa di Kabupaten Gianyar. Secara bersamasama kemandirian secara ekonomi, kemandirian secara intelektual dan kemandirian berorganisasi berperanan positif terhadap BUMDesa di Kabupaten Gianyar.
\end{abstract}

Kata Kunci: $\quad$ BUMDesa; Kemandirian Ekonomi.

\section{Role of BUMDesa in Increasing Village Economic Independence}

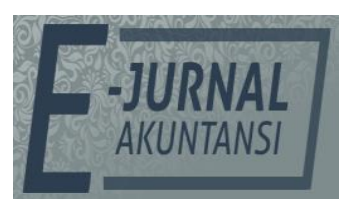

E-JA

e-Jurnal Akuntansi e-ISSN 2302-8556

Vol. 30 No. 6

Denpasar, Juni 2020

Hal.1593-1602

Artikel Masuk:

15 April 2020

Tanggal Diterima: 25 Juni 2020

BUMDesa is an elaboration of the vision of national development that is the realization of a sovereign, independent, and personality based on mutual cooperation. In the Province of Bali only $65 \%$ of the villages have BUMDesa. BUMDesa is expected to be a driving force for the village economy. The purpose of this study is to determine the role of BUMDesa in increasing the economic independence of the village. The population in this study are all village-owned enterprises in the Province of Bali. The location of the study was conducted in Gianyar Regency. The sample collection technique uses purposive sampling. Data collection techniques are carried out through questionnaires. Data analysis techniques using multiple linear regression. This research proves that partially, economic independence has a positive role in BUMDesa in Gianyar Regency. Intellectual independence has a positive role in BUMDesa in Gianyar Regency. And organizational independence has a positive role in BUMDesa in Gianyar Regency. Together economic independence, intellectual independence and organizational independence have a positive role in BUMDesa in Gianyar Regency.

Keywords: BUMDesa; Economic Independence.

The Article is Available in: https://ojs.unud.ac.id/index.php/Akuntansi/index 


\section{PENDAHULUAN}

Teori peran (the role theory) menjelaskan tentang sekumpulan tingkah laku yang dihubungkan dengan suatu posisi tertentu (Sarbin dan Allen, 1968; Biddle dan Thomas, 1966). Asumsi dasar teori peran menyatakan bahwa orang pada dasarnya adalah konformis artinya individu selalu melaksanakan peran mereka dan menampilkan sesuai dengan norma-norma yang berlaku. Peranan merupakan konsep perilaku apa yang diharapkan dilaksanakan oleh para individu dalam masyarakat sebagai organisasi (Soekanto, 2009). Rangkaian peraturan ini akan membimbing seseorang dalam kehidupan kemasyarakatan. Apabila seseorang telah melakukan hak dan kewajibannya sesuai dengan kedudukannya maka dia sudah melaksanakan suatu peran (Berry, 1999).

Peranan lebih banyak menunjuk pada fungsi, penyesuaian diri, dan suatu proses. Peranan memiliki beberapa aspek yaitu: pertama, peranan meliputi norma-norma yang dihubungkan dengan posisi atau tempat seseorang dalam masyarakat. Peranan merupakan rangkaian peraturan yang membimbing seseorang dalam kehidupan masyarakat; kedua, peranan merupakan konsep tentang apa yang dapat dilakukan individu dalam masyarakat sebagai organisasi. Ciri-ciri suatu organisasi terdiri dari dua orang atau lebih, terdapat kerjasama, terdapat komunikasi antar anggota, dan terdapat tujuan yang ingin dicapai (Bernard, 2004) ; ketiga, peranan merupakan perilaku individu yang penting bagi struktur sosial masyarakat desa.

Peranan desa merupakan tindakan yang dilakukan seseorang atau sekelompok orang dalam suatu peristiwa atau bagian yang dimainkan seseorang dalam suatu peristiwa yang terjadi di desa (KBBI, 2018). Didalam peranan diharapkan ada dua macam harapan yaitu: pertama, harapan dari masyarakat desa terhadap pemegang peran atau kewajiban dari pemegang peran; kedua, harapan yang dimiliki oleh si pemegang peran terhadap masyarakat desa atau terhadap orang-orang desa yang berhubungan dengannya dalam menjalankan peranannya atau kewajibannya (Soekamto, 2009). Untuk menilai peranan di desa dapat dilihat dalam beberapa indikator yaitu: pertama, peraturan desa. Peraturan desa akan mengikat semua warga desa, yang dipakai sebagai panduan, tatanan, dan pengendalian tingkah laku agar sesuai dan diterima. Setiap warga desa harus mentaati aturan yang berlaku, kaidah yang dipakai untuk menilai atau membandingkan sesuatu; kedua, konsep. Konsep merupakan gagasan atau ide yang relatif sempurna dan bermakna dalam hal ini konsep dalam mendirikan badan usaha milik desa; ketiga, hak dan kewajiban. Hak merupakan sesuatu hal yang benar, milik, kepunyaan, kewenangan, kekuasaan untuk berbuat sesuatu (KBBI, 2018). Kewajiban merupakan sesuatu yang wajib dilaksanakan oleh masyarakat desa sebagai anggota badan usaha milik desa.

Desa merupakan kesatuan masyarakat hukum yang memiliki batas wilayah yang berwenang untuk mengatur dan mengurus urusan pemerintahan, kepentingan masyarakat setempat berdasarkan prakarsa masyarakat, hak asalusul, dan/atau hak tradisional yang diakui dan dihormati dalam sistem pemerintahan Negara Kesatuan Republik Indonesia (Republik Indonesia, 2014). Desa sudah ada sejak dahulu sebelum Indonesia merdeka. Desa diposisikan sebagai kekuatan besar yang akan memberikan kontribusi besar bagi Indonesia 
agar berdaulat, sejahtera dan bermartabat seperti tercantum dalam UndangUndang Nomor 6 Tahun 2014 tentang desa.

Desa dikatakan mandiri jika desa dapat memenuhi kebutuhannya sendiri dan tidak tergantung dari bantuan pemerintah. Mampu mengatur dan membangun desanya dengan memaksimalkan potensi yang ada di desa serta tidak tergantung pada bantuan pihak luar. Desa mandiri berarti desa yang mempunyai kekuatan secara ekonomi, budaya dan sosial melalui pembangunan dan pemberdayaan masyarakat secara berkesinambungan (Republik Indonesia, 2014). Pemberdayaan (empowerment) berhubungan dengan kekuasaan. Hal ini menunjuk pada kemampuan seseorang untuk memenuhi kebutuhan dasarnya sehingga memiliki kebebasan, dan menjangkau sumber-sumber produktif yang memungkinkan untuk meningkatkan pendapatan dan berpartisipasi dalam proses pembangunan serta keputusan yang mempengaruhi mereka (Suharto, 2005). Tujuan utama pemberdayaan adalah memperkuat kekuasaan masyarakat khususnya kelompok lemah yang memiliki ketidakberdayaan baik karena situasi internal maupun eksternal.

Syarat desa dikatakan mandiri terdiri dari: pertama, melakukan pendayagunaan sumber daya yang ada di desa; kedua, menjalankan penataan serta pembangunan aset dalam desa; ketiga, aktif dalam kelembagaan masyarakat maupun di lingkungan masyarakat; keempat, tersedianya dana atau anggaran desa guna mengelola berbagai kegiatan baik pemberdayaan maupun pembangunan; dan kelima, terdapat kerjasama antar desa dengan pihak lainnya serta pendampingan dalam desa. Untuk mewujudkan kemandirian desa diperlukan strategi pembangunan desa. Strategi pembangunan desa merupakan langkah-langkah yang akan ditempuh oleh seluruh perangkat organisasi desa yang berisi program untuk mewujudkan visi, misi dan tujuan yang telah ditetapkan. Strategi yang umum dilaksanakan dalam membangun kemandirian desa terdiri dari: pertama, membangun kapasitas warga dan organisasi masyarakat sipil di desa dengan kritis dan dinamis; kedua, memperkuat kapasitas pemerintahan dan interaksi dinamis antara organisasi warga dalam menyelenggarakan pemerintahan desa; ketiga, membangun sistem perencanaan dan penyelenggaraan desa yang responsif dan partisipatif; dan keempat, membangun kelembagaan ekonomi lokal yang mandiri dan produktif (Kurniawan, 2015).

Desa tidak berjalan sendiri, pemerintah membuat skala prioritas berbasis pedesaan melalui: pengembangan kelembagaan, pemberdayaan masyarakat, pengembangan ekonomi lokal, pembangunan sarana dan prasarana. Prioritas pengembangan ekonomi lokal ini ditunjukkan melalui BUMDesa. BUMDesa pertama kali muncul dalam Undang-Undang Nomor 32 tahun 2004 tentang Pemerintahan Daerah, Peraturan Pemerintah Nomor 71 Tahun 2005 tentang Desa (Yualita, 2016), Peraturan Menteri Dalam Negeri Nomor 39 Tahun 2010 tentang Badan Usaha Milik Desa, Undang-Undang Nomor 6 Tahun 2014 tentang Desa. BUMDesa merupakan kelembagaan ekonomi yang dikelola sepenuhnya oleh masyarakat desa yaitu dari desa, oleh desa, dan untuk desa dalam rangka meningkatkan kemandirian perekonomian desa. BUMDesa merupakan badan hukum publik yang bercirikan desa dan dapat melakukan usaha bersama secara kooperatif serta memiliki kewajiban patuh terhadap prinsip, semangat serta 
berazaskan kekeluargaan dan gotong royong. BUMDesa merupakan usaha milik desa yang dibentuk oleh pemerintah desa yang kepemilikan modal dan pengelolaannya dilakukan oleh pemerintah desa dan masyarakat desa. BUMDesa diharapkan akan memberikan kontribusi yang signifikan terhadap peningkatan kesejahteraan warga desa. Oleh karena itu BUMDesa bersifat mandiri karena modal usahanya dibangun atas inisiatif masyarakat desa atau bersumber dari masyarakat desa. Keberadaan BUMDesa didukung oleh adat setempat karena sebagai salah satu penyumbang kemakmuran desa. BUMDesa didirikan dengan badan hukum desa melalui peraturan kepala desa yang memiliki Anggaran Dasar/Anggaran Rumah Tangga. Dengan adanya BUMDesa diharapkan tidak terjadi kesenjangan antara masyarakat pedesaan dan perkotaan.

Tujuan didirikan BUMDesa adalah: meningkatkan perekonomian desa, meningkatkan pendapatan asli desa, meningkatkan pengelolaan potensi desa sesuai dengan kebutuhan masyarakat, dan menjadi tulang punggung pertumbuhan dan pemerataan ekonomi desa. Tujuh indikator untuk menilai perkembangan BUMDesa terdiri dari: kelembagaan; aturan legalitas; usaha BUMDesa; administrasi, pelaporan, dan pertanggungjawaban; permodalan dan aset; dampak BUMDesa terhadap masyarakat desa; dampak bagi pembangunan desa (Subagyo, 2000). Badan Permusyawarahan Desa (BPD), berhak menyelenggarakan musyawarah desa untuk membahas lahirnya Badan Usaha Milik Desa (BUMDesa). Pembahasan BUMDesa dihadiri oleh kepala desa beserta perangkatnya, Badan Permusyawarahan Desa selaku pengawas desa (sesuai dengan Peraturan Menteri Dalam Negeri Nomor 110 tahun 2016), Lembaga Kemasyarakatan Desa (sesuai dengan Peraturan Menteri Dalam Negeri Nomor 18 tahun 2018) beserta tokoh-tokoh masyarakat.

Kekayaan BUMDesa dipisahkan dengan kekayaan desa. Aset BUMDesa berasal dari keikutsertaan modal dari pemerintah desa dan modal dari masyarakat desa. BUMDesa harus memiliki perencanaan yang matang dan komitmen yang kuat untuk meningkatkan kesejahteraan seluruh warga desa. Struktur organisasi BUMDesa terbagi atas: penasehat, pelaksana operasional dan pengawas. Pendapatan asli desa merupakan cerminan dari kemadirian pemerintahan desa dalam melaksanakan proses pembangunan. Penelitian yang dilakukan Atmojo (2015) menemukan bahwa BUMDesa Temurejo Banyuwangi berperanan dalam memberdayakan ekonomi masyarakat menengah kebawah melalui pinjaman modal usaha. Hipotesis yang diajukan adalah:

$\mathrm{H}_{1}$ : Kemandirian secara ekonomi berperanan positif terhadap BUMDesa di Kabupaten Gianyar.

Demikian pula kapasitas sumber daya manusia merupakan faktor penting dalam mencari alternatif pendapatan asli desa. Partisipasi masyarakat desa harus dibangkitkan untuk mendukung kemandirian ekonomi desa (Atmojo, 2015). Hipotesis yang diajukan adalah:

$\mathrm{H}_{2}$ : Kemandirian secara intelektual berperanan positif terhadap BUMDesa di Kabupaten Gianyar.

Kemandirian desa berarti kapasitas dan inisiatif lokal yang kuat. Inisiatif lokal berupa gagasan, kehendak, kemauan entitas desa yang berbasis pada kearifan lokal, komunalisme dan modal sosial (kepemimpinan, jaringan dan solidaritas 
sosial. Inisiatif lokal yang kuat merupakan fondasi lokal bagi kemandirian desa (Ermaya, 2015). Penelitian yang dilakukan oleh Sagita (2017) menemukan bahwa BUMDesa Tirta Mandiri Desa Ponggok Jawa Tengah yang bergerak dibidang pariwisata dan sarana pendukungnya, pengelolaannya lebih tepat melalui BUMDesa dibandingkan dibawah pengelolaan koperasi. Hipotesis yang diajukan adalah:

$\mathrm{H}_{3}$ : Kemandirian berorganisasi berperanan positif terhadap BUMDesa di Kabupaten Gianyar.

Secara bersama-sama

$\mathrm{H}_{4}$ : Kemandirian ekonomi, kemandirian intelektual, dan kemandirian berorganisasi secara bersama-sama berperanan terhadap BUMDesa di Kabupaten Gianyar.

\section{METODE PENELITIAN}

Populasi dalam penelitian ini adalah seluruh BUMDesa yang terdapat di Provinsi Bali. Teknik pengumpulan sampel menggunakan purposive sampling. Teknik pengumpulan data dilakukan melalui penyebaran kuesioner. Untuk menguji instrumen penelitian dilakukan uji validitas dengan menggunakan pearson correlation, uji reliabilitas menggunakan cronbach's alpha. Untuk menguji model dilakukan uji asumsi klasik yaitu: pertama, uji normalitas menggunakan kolmogorov-smirnov untuk mengetahui apakah tiap variabel berdistribusi normal ataukah tidak, dengan kriteria jika asymp-sig (2 tailed) lebih besar dari 0,05 maka data tersebut berdistribusi normal; kedua, uji multikolinieritas untuk menguji ada tidaknya hubungan antar variabel bebas, dan juga digunakan untuk menguji apakah dalam persamaan regresi terdapat korelasi antar variabel bebas. Jika nilai variance inflation factor (VIF) lebih kecil dari 10 dan nilai tolerance lebih besar dari 0,1 maka model regresi tidak mengandung multikoleniaritas; ketiga, uji heterokedastisitas untuk mengetahui apakah ada ketidaksamaan varian dari residual untuk semua pengamatan pada model regresi linier berganda. Uji heteroskedastisitas menggunakan metode glejser. Jika sig-t hitung lebih besar dari 0,05 maka tidak terjadi heteroskedastisitas. Untuk menguji hipotesis digunakan regresi linier berganda dengan taraf signifikansi 5\% (Sugiyono, 2017) dengan persamaan:

$$
\mathrm{Y}=\mathrm{a}+\mathrm{b} 1 \mathrm{X} 1+\mathrm{b} 2 \times 2+\mathrm{b} 3 \times 3+\mathrm{e}
$$

Keterangan:

$$
\begin{array}{ll}
\mathrm{Y}=\text { Peranan Bumdesa } & \mathrm{X} 1=\text { Kemandirian ekonomi } \\
\mathrm{a}=\text { Konstanta } & \mathrm{X} 2=\text { Kemandirian intelektual } \\
\mathrm{b} 1, \mathrm{~b} 2, \mathrm{~b} 3=\text { Koefisien regresi } & \mathrm{X} 3=\text { Kemandirian berorganisasi } \\
\mathrm{e}=\text { error } &
\end{array}
$$

\section{HASIL DAN PEMBAHASAN}

Kabupaten Gianyar memiliki 70 desa. Hasil penyebaran kuesioner yang telah dilakukan diperoleh 100 jawaban responden yang memenuhi kriteria. Hasil uji normalitas menunjukkan asymp-sig ( 2 tailed) bernilai 0,357 >0,05 berarti data berdistribusi normal. 
Tabel 1. Hasil Uji Normalitas

\begin{tabular}{|c|c|c|c|}
\hline \multicolumn{4}{|c|}{ One-Sample Kolmogorov-Smirnov Test } \\
\hline & & & $\begin{array}{l}\text { Unstandarized } \\
\text { Residual }\end{array}$ \\
\hline \multicolumn{2}{|l|}{$\overline{\mathrm{N}}$} & & 100 \\
\hline \multirow[t]{2}{*}{ Normal Parameters } & $a, b$ & Mean & .0000000 \\
\hline & & Std. Deviation & .32468734 \\
\hline \multicolumn{2}{|l|}{ Most Extreme } & Absoulute & .093 \\
\hline \multirow{2}{*}{\multicolumn{2}{|c|}{ Differences }} & Positive & .093 \\
\hline & & Negative & .056 \\
\hline \multicolumn{3}{|c|}{ Kolmogorov-Smirnov Z } & .926 \\
\hline \multicolumn{3}{|l|}{ Asymp.sig. (2-tailed) } & .357 \\
\hline
\end{tabular}

a. Test distribution is normal.

b. Calculated from data.

Sumber: Data Penelitian, 2020

Hasil uji multikolinieritas menunjukkan nilai VIF untuk kemandirian secara ekonomi, kemandirian secara intelektual dan kemandirian berorganisasi nilainya lebih kecil dari 10 dan nilai tolerance lebih besar dari 0,1 berarti tidak mengandung multikolinieritas.

Tabel 2. Hasil Uji Multikolinieritas

\begin{tabular}{|c|c|c|c|c|c|c|c|}
\hline \multicolumn{8}{|c|}{ Coefficients } \\
\hline Model & \multicolumn{2}{|c|}{$\begin{array}{l}\text { Unstandarized } \\
\text { Coefficients }\end{array}$} & \multirow{2}{*}{$\begin{array}{l}\text { Standarized } \\
\text { Coefficients } \\
\text { Beta }\end{array}$} & \multirow[t]{2}{*}{$\mathrm{t}$} & \multirow[t]{2}{*}{ Sig. } & \multicolumn{2}{|c|}{$\begin{array}{c}\text { Collinearity } \\
\text { Statistics }\end{array}$} \\
\hline & $\bar{B}$ & $\begin{array}{l}\text { Std. } \\
\text { Error }\end{array}$ & & & & Tolerance & VIF \\
\hline 1 (Constant) & .119 & .285 & & .417 & .678 & & \\
\hline $\begin{array}{l}\text { Kemandirian } \\
\text { Ekononomio }\end{array}$ & .395 & .085 & .361 & 4.624 & .000 & .603 & 1.657 \\
\hline $\begin{array}{l}\text { Kemandiian } \\
\text { Intelektual }\end{array}$ & .307 & .100 & .319 & 3.067 & .003 & .339 & 2.947 \\
\hline $\begin{array}{l}\text { Kemandirian } \\
\text { Berorg. }\end{array}$ & .251 & .110 & .236 & 2.268 & .026 & .339 & 2.945 \\
\hline
\end{tabular}

a. Dependent Variable: Peran BUMDesa

Sumber: Data Penelitian, 2020

Hasil uji heteroskedastisitas menunjukkan nilai signifikansi kemandirian ekonomi, kemandirian intelektual, kemandirian berorganisasi semuanya memiliki nilai lebih besar dari 0,05 berarti tidak terjadi heteroskedastisitas. 
Tabel 3. Hasil Uji Heteroskedastisitas

\begin{tabular}{|c|c|c|c|c|c|}
\hline & & icients & & & \\
\hline Model & Unsta & Coefficients & Standarized & $\mathrm{t}$ & Sig. \\
\hline & $B$ & Std. Error & Beta & & \\
\hline 1 (Constant) & .586 & .190 & & 3.088 & .003 \\
\hline Kemandirian & -.085 & .057 & -.191 & - & .140 \\
\hline Ekononomio & & & & 1.489 & \\
\hline Kemandiian Intelektual & -.034 & .067 & -.087 & -.506 & 614 \\
\hline Kemandirian Berorg. & .028 & .073 & .065 & .379 & .706 \\
\hline
\end{tabular}

a. Dependent Vriable: Abress

Sumber: Data Penelitian, 2020

Hasil uji linieritas menunjukkan nilai $\mathrm{F}$ hitung sebesar 1,482 dengan tingkat signifikansi 0,224.

Tabel 4. Uji Statistik Linieritas

\begin{tabular}{|c|c|c|c|c|c|}
\hline \multicolumn{6}{|c|}{$\overline{A N O V A^{b}}$} \\
\hline Model & $\begin{array}{l}\text { Sum Of } \\
\text { Squaress }\end{array}$ & $\overline{d f}$ & $\begin{array}{l}\text { Mean } \\
\text { Square }\end{array}$ & $F$ & Sig. \\
\hline \multirow[t]{3}{*}{ Regression } & .214 & 3 & .071 & \multirow[t]{3}{*}{1.482} & \multirow[t]{3}{*}{$.224^{a}$} \\
\hline & 4.617 & 96 & \multirow[t]{2}{*}{.048} & & \\
\hline & 4.830 & 99 & & & \\
\hline \multicolumn{6}{|c|}{$\begin{array}{l}\text { a. Predictors: (Constant), Kemandirian Berorg., Kemandirian Ekononomio, } \\
\text { Kemandirian Intelektual } \\
\text { b. Dependent Variable: Abress } \\
\text { Sumber: Data Penelitian, } 2020 \\
\text { Uji statistik deskriptif terhadap } 100 \text { responden menunjukkan nilai rata- } \\
\text { rata kemandirian secara ekonomi, kemandirian secara intelektual dan } \\
\text { kemandirian secara organisasi mendekati nilai 3,8 artinya mendekati sangat } \\
\text { setuju. } \\
\text { Tabel 5. Uji Statistik Deskriptif }\end{array}$} \\
\hline \multicolumn{6}{|c|}{ Descriprive Statistic } \\
\hline & Mean & & Std. Deviation & & $\mathrm{N}$ \\
\hline Peran BUMDesa & 3.8080 & & .54674 & & 100 \\
\hline $\begin{array}{l}\text { Kemandirian } \\
\text { Ekononomio }\end{array}$ & 3.8592 & & 49918 & & 100 \\
\hline $\begin{array}{l}\text { Kemandiian } \\
\text { Intelektual }\end{array}$ & 3.8847 & & .56886 & & 100 \\
\hline $\begin{array}{l}\text { Kemandirian } \\
\text { Berorg. }\end{array}$ & 3.8829 & & .51523 & & 100 \\
\hline
\end{tabular}

Sumber: Data Penelitian, 2020 
Hasil pengujian secara parsial menunjukkan kemandirian secara ekonomi berperanan positif terhadap BUMDesa di Kabupaten Gianyar terbukti. Hal ini ditunjukkan dengan nilai signifikan sebesar 0,000 $<0,05$ sehingga hipotesis pertama diterima. Kemandirian secara intelektual berperanan positif terhadap BUMDesa di Kabupaten Gianyar terbukti dengan nilai signifikansi sebesar 0,000 $<0,05$ sehingga hipotesis kedua diterima. Sedangkan kemandirian berorganisasi memperoleh nilai signifikansi 0,026 <0,05 artinya hipotesis ketiga diterima yaitu kemandirian secara organisasi berperanan positif terhadap BUMDesa di Kabupaten Gianyar.

Tabel 6. Hasil Pengujian Secara Parsial

\begin{tabular}{|c|c|c|c|c|c|c|c|}
\hline \multicolumn{8}{|c|}{ Coefficients } \\
\hline Model & \multicolumn{2}{|c|}{$\begin{array}{l}\text { Unstandarized } \\
\text { Coefficients }\end{array}$} & \multirow{2}{*}{$\begin{array}{l}\begin{array}{l}\text { Standarized } \\
\text { Coefficients }\end{array} \\
\text { Beta }\end{array}$} & \multirow[t]{2}{*}{$\mathrm{t}$} & \multirow[t]{2}{*}{ Sig. } & \multicolumn{2}{|c|}{$\begin{array}{c}\text { Collinearity } \\
\text { Statistics }\end{array}$} \\
\hline & $\bar{B}$ & $\begin{array}{l}\text { Std. } \\
\text { Error }\end{array}$ & & & & Tolerance & VIF \\
\hline 1 (Constant) & .119 & .285 & & .417 & .678 & & \\
\hline $\begin{array}{l}\text { Kemandirian } \\
\text { Ekononomio }\end{array}$ & .395 & .085 & .361 & 4.624 & .000 & .603 & 1.657 \\
\hline $\begin{array}{l}\text { Kemandiian } \\
\text { Intelektual }\end{array}$ & .307 & .100 & .319 & 3.067 & .003 & .339 & 2.947 \\
\hline $\begin{array}{l}\text { Kemandirian } \\
\text { Berorg. }\end{array}$ & .251 & .110 & .236 & 2.268 & .026 & .339 & 2.945 \\
\hline
\end{tabular}

a. Dependent Variable: Peran BUMDesa

Sumber: Data Penelitian, 2020

Hasil uji secara bersama-sama menunjukkan nilai signifikansi sebesar $0,000<0,05$ artinya secara bersama-sama kemandirian secara ekonomi, kemandirian secara intelektual, dan kemandirian berorganisasi berperanan positif terhadap BUMDesa di Kabupaten Gianyar.

Tabel 7. Hasil Uji Secara Bersama-Sama

\begin{tabular}{|c|c|c|c|c|c|}
\hline & & $\overline{N O}$ & & & \\
\hline Model & Sum Of & $\overline{d f}$ & Mean & $F$ & Sig. \\
\hline 1 Regression & 19.157 & 3 & 6.386 & 58.736 & $.000^{\mathrm{a}}$ \\
\hline Residual & 10.437 & 96 & .109 & & \\
\hline Total & 29.594 & 99 & & & \\
\hline
\end{tabular}

a. Predictors: (Constant), Kemandirian Berorg., Kemandirian Ekononomio,

Kemandirian Intelektual

b. Dependent Variable: Abress

Sumber: Data Penelitian, 2020 
Hasil penelitian ini mendukung penelitian dari Atmojo (2015) dan Sagita (2017) yang menyatakan BUMDesa berperanan dalam meningkatkan kemandirian ekonomi desa.

\section{SIMPULAN}

Hasil penelitian menunjukkan kemandirian secara ekonomi berperanan positif terhadap BUMDesa di Kabupaten Gianyar. Kemandirian secara intelektual berperanan positif terhadap BUMDesa di Kabupaten Gianyar. Kemandirian berorganisasi berperanan positif terhadap BUMDesa di Kabupaten Gianyar. Dan secara bersama-sama penelitian ini menemukan kemandirian secara ekonomi, kemandirian secara intelektual, dan kemandirian berorganisasi berperanan positif terhadap BUMDesa di Kabupaten Gianyar. Untuk penelitian berikutnya dapat menambahkan variabel ketepatan penggunaan dana, tingkat pengembalian dana dan pelatihan sumber daya manusia BUMDesa dalam meningkatkan kemandirian ekonomi desa.

\section{REFERENSI}

Atmojo, Singgih Tri. 2015. Peran Badan Usaha Milik Desa (BUMDes) Dalam Pemberdayaan Masyarakat Desa (Studi Kasus Pada Badan Usaha Milik Desa (BUMDes) Di Desa Temurejo Kecamatan Bangorejo Kabupaten Banyuwangi). Skripsi. Universitas Jember.

Balipost, 2018. www.balipost.com/news/2018/01/27/35732/angkatperekonomian-desa, Bumdes-jangan...html/diunduh 17/02/2018 $\mathrm{pk} / .10 .00$.

Bermard, Weiner. 2004. Attribution Theory Revisited: Transforming Cultural Plurarity into Theoritical Unity. In Big Theories Revisited, Edited by D.M. McInerney \& S. Van Etten, 13-29. Greenwich, CT, Information Age Publishing.

Berry, Devit. 1999. Pokok-Pokok Pikiran dalam Sosiologi. Jakarta, CV. Raja Wali. P 105.

Biddle, Bruce J dan Thomas E.J. 1966. Role Theory: Concept and Research. New York: Oxford, England: John Wiley, pp 67-72.

Ermaya, Berna Sudjana. 2015. Kemandirian Desa dalam Mewujudkan Pembangunan Kawasan Pedesaan. Jurnal Litigasi. Vol 16 (2), pp 28352874.

KBBI. 2018. https://kbbi.kemdikbud.go.id.

Kurniawan, Boni. 2015. Desa Mandiri, Desa Membangun. Jakarta, Kementerian Desa, Pembangunan Daerah Tertinggal, dan Transmigrasi Republik Indonesia.

Republik Indonesia. 2010. Peraturan Menteri Dalam Negeri Nomor 39 Tahun 2010 tentang Badan Usaha Milik Desa.

Republik Indonesia. 2014. Undang-Undang Nomor 6 Tahun 2014 tentang Desa. Republik Indonesia. 2016. Peraturan Menteri Dalam Negeri Nomor 110 Tahun 2016 tentang Badan Permusyawaratan Desa

Republik Indonesia. Undang-Undang Nomor 32 Tahun 2004 tentang Pemeritah Daerah. 
Sagita, Garnies Lellyana. 2017. Peranan Badan Usaha Milik Desa Dalam Meningkatkan Kesejahteraan Masyarakat Desa Berdasarkan UU No. 6 Tahun 2014 Tentang Desa. Skripsi. Fakultas Hukum Universitas Muhammadiyah Surakarta.

Sarbin, Theodore R dan Vernon L. Allen. 1968. Role Theory. In Handbook of Social Psychology. 2nd Ed. Editedby Gardner Lindzey and Elliot Aronson, pp. 488-567. Reading MA: Addison-Wesley Publishing Company.

Sholeh, A. Susanto F, dan Susanti R. 2017. Persepsi Aparatur Pemerintah Desa Terhadap Dana Desa Di Kecamatan Seluma Barat Kabupaten Seluma. Ekombis Review. Bengkulu. Universitas Dehasen Bengkulu.

Soekanto, Soerjono. 2009. Sosiologi Suatu Pengantar, Edisi Baru. Jakarta, Rajawali Press.

Subagyo, Ahmad Wito. 2000. Efektivitas Program Penanggulangan Kemiskinan dan Pemberdayaan Masyarakat Pedesaan. Tesis. Yogyakarta, UGM.

Sugiyono, 2017. Metode Penelitian Kuantitatif, Kualitatif, dan R\&D. Bandung, Alfabeta.

Suharto, Edi. 2005. Membangun Masyarakat Memberdayakan Raky at. PT. Refika Aditama, 2005, pp 57-60.

Yualita, Rahma. 2016. Efektivitas Pelaksanaan Penggunaan Alokasi Dana Desa di Desa Setako Raya Kecamatan Peranap Kabupaten Indragiri Hulu. JOM Fisip Vol 3, No. 2. Universitas Riau.

Republik Indonesia. 2018. Peraturan Menteri Dalam Negeri Nomor 18 Tahun 2018 tentang Lembaga Kemasyarakatan Desa. 